\title{
ŽMOGAUS SU PSICHINE NEGALIA NEVEIKSNUMO KONSTRAVIMAS: SOCIALINIO DARBUOTOJO DILEMOS
}

\author{
GIEDRIUS ZATURSKIS \\ RESPUBLIKINE KLAIPĖDOS LIGONINÉ \\ ASTA KIAUNYTE் \\ KLAIPÉDOS UNIVERSITETAS
}

Kuratela "dokumentu, <... buvo skelbiamas neveiksniu, <..> summa summarum jis buvo skelbiamas nullum..."

Kristina Sabaliauskaitė, Silva Rerum III

Straipsnyje analizuojamas žmogaus su psichine negalia neveiksnumo konstravimas, remiantis socialiniu darbuotoju patirtimi. Pristatomas kritiškas požiūris i institucionalizuota neveiksnumo konstravimo socialinę tikrovę, grista žinojimo praktika; aktualizuojamas socialinio darbo refleksyvus pobūdis bei dialogiškas santykis; teikiamos rekomendacijos žmogaus su psichine negalia neveiksnumo proceso koregavimui.

\section{IVADAS}

Lietuvoje žmogaus su psichine negalia tapimo neveiksniu procesas kelia daug aktualių klausimų. Socialiniam darbuotojui kyla dilema, kodèl nustatant žmogui su psichine negalia neveiksnumą dažniausiai vadovaujamasi vienu kriterijumi - medicininiu, t. y. atsižvelgiama i psichikos ligos diagnozę, nors nustatant neveiksnumą būtina atsižvelgti i du kriterijus: medicininị - psichinę ligą ar proto negalią ir juridinị, socialinị nesugebėjimą suprasti savo veiksmų reikšmės ir jų valdyti. LR Civilinio kodekso 2.10 straipsnis nurodo būtinumą atsižvelgti i šiuos du kriterijus. 
Neveiksnuma, globą ir rūpybą reguliuoja teisinè institucija, reglamentuoja LR Civilinio proceso kodeksas (2002) ir LR Civilinis kodeksas (2004). Kyla pavojus, kad vykstant teisiniam neveiksnumo statuso pripažinimo procesui pažeidžiamos asmens su psichine negalia pagrindinès žmogaus teisès, nes neveiksnus asmuo praranda teisę i darbą, santuoka, teisę balsuoti, disponuoti savo nuosavybe, be to, kreiptis ì teismą dèl neveiksnaus asmens statuso peržiūrèjimo. Tai pažeidžia LR Konstitucijos 30 straipsni bei Europos žmogaus teisių ir pagrindinių laisvių apsaugos konvencija, visiems garantuojančią teisę kreiptis į teismą dèl civilinių teisių ir pareigų. Lietuvoje iki šiol nebuvo numatyta periodinè neveiksnumo peržiūrèjimo galimybè. Neveiksnumas, dèl psichikos sutrikimo nustatomas visam likusiam gyvenimui, anot Germanavičiaus (2008), prieštarauja moderniam psichiatrijos mokslui, medicinos etikai, žmogaus teisėms ir paciento autonomijos skatinimo principui. Kyla grèsmè, kad neveiksnus asmuo, be civilinių teisių praradimo, praranda bet kokias elementariausias teises - jis patiria "teisinę ir socialinę mirtį", yra tarsi „ištrinamas“ iš visuomenès. Wardas (1999) jau prieš 15 metų teikè savo pasiūlymus Rytų Europos valstybėms, kaip modernizuoti neveiksnumo institutą. JT Žmogaus teisių komitetas, Europos žmogaus teisių teismas yra pareiškę susirūpinimą dèl neveiksnių asmenų padėties Lietuvoje.

Egzistuoja esminis skirtumas, kaip visiško ir riboto neveiksnumo paskyrimo procesas vyksta užsienio valstybių ir Lietuvos neveiksnumo institutuose. Lietuvoje, pagal LR Civilini kodeksa, ribotai veiksniais gali būti tik nuo alkoholio, narkotinių ar toksinių medžiagų priklausomi asmenys. Žmonès su psichine negalia negali būti pripažinti ribotai veiksniais. Žmonès su psichine negalia gali būti pripažinti tik visiškai neveiksniais. Iki šiol jokių išlygų LR Civiliniame kodekse nebuvo, nors JT Neigaliujų teisių konvencijos 12 straipsnio 3 dalis ipareigoja Konvencijos šalis imtis atitinkamų priemonių, kad suteiktų neigaliesiems galimybę pasinaudoti pagalba, kurios jiems gali prireikti igyvendinant savo teisini veiksnumą. Tačiau Lietuvoje iki šiol nebuvo numatyta nustatyti ribotą veiksnumą asmenims su psichine negalia, nors ratifikuodamos šią Konvenciją šalys prisièmė îsipareigojimą ją vykdyti. Tik šiuo metu LR Vyriausybei pateiktas Civilinio kodekso pakeitimo įstatymo projektas, kuriuo numatomi pakeitimai atsižvelgiant i tarptautinius dokumentus. 
Ribotas veiksnumo institutas daugelyje Europos valstybiu (Lenkijoje, Estijoje, Kroatijoje, Vokietijoje, Čekijoje ir kt. šalyse), anot AndrikienèsPūraitès (2012), jau yra ịtvirtintas ir įsigaliojęs. Čekijoje numatyta teisè, kad inicijuoti veiksnumo atkūrimo procedūrą kreipiantis ị teismą gali ir pats globojamas, neveiksnus asmuo. Neveiksnus asmuo periodiškai gali reikalauti naujos neveiksnumo patikrinimo išvados. Visiško neveiksnumo institutas, Čekijos Konstitucinio teismo nuomone, yra sovietinio režimo atgyvena ir praktikoje sunkiai igyvendinamas. Suomijos teisinejje sistemoje neveiksnumas pripažǐstamas kraštutiniu atveju, jeigu neužtenka alternatyvių priemonių. Veiksnumas ribojamas tiek, kiek reikia asmens interesams saugoti. Radavičiaus (2004) teigimu, Didžiojoje Britanijoje visiško ir dalinio neveiksnumo institutų skirtumai atsispindi turto valdymo santykiuose. Patikèti valdyti savo turtą gali pats psichine liga sergantis asmuo arba teismas gali paskirti turto globą. Igaliojimo, kuris yra parašytas sergančio psichikos liga asmens, pripažinimas tarsi pripažìsta dalinį asmens veiksnumą.

Germanavičiaus, Povilaitienės (2010) nuomone, nuo psichikos ligos niekas nèra apsaugotas, nes psichikos ligos nèra nei retos, nei neịprastos, jos dažnos - pasaulyje kas ketvirtas žmogus yra susidūręs su psichinės sveikatos sutrikimu, kai jam prireikè profesionalios pagalbos. Psichinė negalia dažnai sukelia laikinas neveiksnumo apraiškas ir nebūtinai yra pastovi žmogaus būsena.

Nevyriausybinės organizacijos: „Psichikos sveikatos perspektyvos“, klubas „13 ir Ko“, „Žmogaus teisių stebèjimo institutas “ ir kt. pastoviai kelia klausimus dèl neveiksnių asmenų žmogaus teisių užtikrinimo. Lietuvos Respublikos Vyriausybės psichikos sveikatos strategijos igyvendinimo 2011-2013 metų tarpinstituciniame veiklos plane buvo numatyta sukurti naują žmonių su psichine negalia teisių gynimo strategiją. Teisingumo ministerijos sudaryta darbo grupè teikė pasiūlymus dèl neveiksnumo instituto koregavimo. Nuo $2014 \mathrm{~m}$. sausio $1 \mathrm{~d}$. įsigaliojo Civilinio proceso kodekso 466 str. 2 ir 3 dalių nuostatos, ippareigojančios teisejją pranešti asmeniui, kuri prašoma pripažinti neveiksniu, jog būtina, kad jam atstovautų advokatas. Tai reikšmingas teisinis žingsnis atstovaujant žmogaus su psichine negalia teisèms ir interesams ir juos ginant.

Socialiniam darbui aktualūs neveiksnumo psichosocialiniai aspektai, psichinès ligos ir neveiksnumo santykis, asmens su psichine negalia vaidmens transformacijos bei adaptacija visuomenèje. Neveiksnumą psichinès negalios kontekste tyrinèjo Andrikienè-Pūraitė (2012), 
Germanavičius, Povilaitienė (2010), Kriščiūnas (2002), Nemanytė (2012), Radavičius (2004), Wardas (1999), Samsonienè (2011) ir kt., tačiau pasigendama socialinių darbuotoju, kaip profesinės bendruomenės, išsakytos nuomonès neveiksnumo klausimu.

Tyrimo probleminiai klausimai: kaip psichinè negalia formuoja neveiksnumo socialinį konstravimą? Kaip socialiai konstruojamas žmogaus su psichine negalia neveiksnumas pažeidžia žmogaus teises, neigia socialinio darbo vertybes bei kelia socialiniam darbuotojui profesines dilemas? Koks socialinio darbuotojo, kaip institucijos atstovo, vaidmuo socialiai konstruojant neveiksnumą?

Šio straipsnio tyrimo objektas - žmogaus su psichine negalia neveiksnumo konstravimas. Tikslas - atskleisti žmogaus su psichine negalia neveiksnumo konstravimo institucionalizuotą praktika, aktualizuojant socialinių darbuotojų dilemas.

Tyrimo imtis ir vieta. Tyrimas buvo atliktas 2013 metais, apklausti 6 socialiniai darbuotojai, dirbantys Klaipėdos mieste. Tyrimui pasirinkta tikslinė, kriterinè atranka, kai išskiriami keli atrankos kriterijai, šiuo atveju: 1) socialiniai darbuotojai, dirbantys su žmonėmis, turinčiais psichinę negalia; 2) socialiniai darbuotojai, dalyvaujantys neveiksnumo pripažinimo procese.

Tyrimo metodai: žmogaus su psichine negalia neveiksnumo konstravimą siekiama atskleisti remiantis unikalia socialinių darbuotoju patirtimi. Tyrimo pažinimo objektas pasirinktas remiantis fenomenologine strategija, kurios pagrindinis dalykas, anot Finlay (2012), - atsigręžimas ị turimų patirčių prasmes. Kitaip sakant, siekiant atskleisti tyrinėjamą reiškinį, skolinamasi kitų žmonių patirtis. Kokybinis tyrimas padeda išgauti gilesnius informacijos klodus su subjektyvia respondento nuomone. Socialinio konstravimo prasme, kokybinis tyrimas stengiasi parodyti gyvenimo faktus, reiškinius tokius, kokius juos mato ir suvokia tyrimo metu apklausiami žmonės. Kiekvienas žmogus yra unikali asmenybė, todèl savaip suvokia socialinę tikrovę, jos désnius. Socialinio darbuotojo susiformavusi darbinė patirtis lemia subjektyvią nuomonę kiekvienu gyvenimo atveju.

Duomenims rinkti buvo pasirinktas interviu metodas, naudingas tuo, kad kiekvieno respondento asmeninès problemos formulavimas sava kalba teikia individualių duomenų ir atskleidžia skirtingas patirtis. Tyrimo rezultatai pateikti atliekant kokybinę turinio analizę. 
INSTITUCIONALIZUOTAS NEVEIKSNUMO KONSTRAVIMAS: NUO ŽINOJIMO DIALOGO LINK. Neveiksnumo konstravimo esmè slypi požiūryje ị neigalų asmenį, o vienas iš būdų tai paaiškinti yra žinojimo sociologija (Berger, Luckmann, 1999). Autorių pagrindinè mintis yra ta, kad visas mus supantis pasaulis yra žmonių sukonstruotas pasaulis. Žmogus gyvendamas pasaulyje atlieka daug veiksmų, kurie būna rutininiai, pasikartojantys, nuobodūs, todèl individas juos habitualizuoja: „kiekvienas dažnai kartojamas veiksmas tampa šablonu, kuri galima pakartoti sutaupant pastangų ir kuri ipso facto jo atlikèjas suvokia kaip tą šabloną. Be to, habitualizacija reiškia, kad ši veiksmą bus galima atlikti ateityje tokiu pat būdu ir sutaupant pastangų" (p. 74).

Habitualizaciją Jungas (Perminas ir kt. 2004) aiškina archetipų sąvoka. Archetipai, pasak Jungo, yra universali minties idejja, kuri turi stiprią emocinę galią. Tai pirminès, igimtos, pačios bendriausios suvokimo ir elgesio schemos, lemiančios individo sąmonès turinį ir elgesị, tačiau tiesiogiai sąmonėje ar elgesiu nepasireiškiančios. Archetipas, kaip ir habitualizacija, atsiranda pasikartojant tiems patiems išgyvenimams iš kartos i kartą. Jungas teigia, kad archetipu yra neribotas kiekis ir jie visi telpa "kolektyvinėje pasąmonèje“.

Habitualizuoti veiksmai, kaip savaime ir visiems vienodai suprantami, tampa institucijos procesų dalimi. Pasak Bergerio ir Luckmanno (1999), kiekviena institucija siekia kontroliuoti žmogaus elgseną pagal pripažǐstamus šablonus, kiekviena institucija turi savo istoriją. Žmogui evoliucijos eigoje būdinga sudaiktinti savo susikurtus institutus. Jie tampa nebe subjektyvia, o objektyvia realybe, kaip duotybe. Sukuriamas institucijų pasaulis, kuriame kiekvienas individas „žino“ savo vietą ir gyvenimo tikslą. Atsiradus deviacijoms, kitokiems žmonėms, kitokiam elgesiui, nuomonėms apie kitoki pasaulio supratimą išskiriamos normalumo ir nenormalumo (devianto) sąvokos. Kitoks tampa iššūkiu sistemai.

Pripažindami, kaip teigia Payne (2005), kad visuomenèje tokie procesai vyksta, privalome pripažinti, kad jie gali vykti ir socialinio darbo, kuris yra vienas iš visuomenès kaip socialinès sistemos komponentu, terpèje. Sąveika tarp socialinio darbo elementų: socialinio darbuotojo, kliento ir konteksto konstruojama pagal nusistovèjusius elgesio modelius, lūkesčius ir kultūrines normas. Socialinis darbuotojas ir klientas susitinka kaip socialinių vaidmenų atlikėjai, kurių veiksmus sąlygoja visuomenès kontekstas. 
Žmogaus su psichine negalia kaip socialinio darbo kliento vaidmuo yra sudètingas ir socialiai konstruojamas priklausomai nuo paties asmens požiūrio ị save, artimụjų, specialistų ir visuomenės nuomonės. Pivorienès (2003) teigimu, neigalūs žmonės yra ne neigalumo, o stigmatizacijos aukos. Psichinès negalios socialinė būklè priklauso nuo socialinių tikrovès apibrèžimų ir pati yra socialiai apibrèžta.

Socialinio darbuotojo profesinis vaidmuo nevienareikšmis tuo aspektu, kad susiduriama su profesine dilema. Kaip socialiniam darbuotojui tuo pat metu atstovauti žmogui su psichine negalia, ginti jo kaip kliento interesus ir būti lojaliam visuomenès institucijai? Kaip socialiniam darbuotojui laikytis etikos kodekso (1998), kuriame nurodoma, jog pagrindinè socialinio darbo idejja - ginti žmogu kaip individualybę ir vertybę, puoselèti jo teisę i apsisprendimą kai socialinio darbuotojo vaidmuo vykstant žmogaus su psichine negalia pripažinimo neveiksniu procesui nėra įteisintas ir apibrèžtas. Kaip socialiniam darbuotojui laikytis etikos normų ir principų, kurie nurodo gerbti pagrindines pavienių individų bei grupių teises, remiantis JT Visuotine žmogaus teisių deklaracija (2006) bei kitomis tarptautinemis konvencijomis, jei nėra prisiimti įsipareigojimai jų laikytis instituciniu lygmeniu? Socialiniai darbuotojai susiduria su vidinėmis ir išorinėmis dilemomis. Vienos jų kyla iš santykio su savimi sprendžiant moralinius klausimus, sąlygojamus asmeninio ir profesinio vaidmens konflikto. Kitos - iš santykių su klientais, kolegomis, vadovu, organizacija, jos veiklos principais ar santykio su visuomene. Šios socialinio darbuotojo vaidmens dilemos kelia vidinę i̇tampa, skatina reflektuoti praktinę patirti, ieškoti nauju išeičių bei kurti tokius santykius, kuriuose vyrautų dialogas. Gergenas, McNamee, Barrettas (2001), analizuodami transformuojanti dialoga, kylančias tendencijas įžvelgia nagrinėdami problemą ivvairiais aspektais. Autoriai teigia, jog pirmiausia mes stengiamès išvengti to, kas yra skirtinga ir ypač, kas gyvenime atrodo priešiška. Vengiame susitikimų, pokalbių, socialinių susibūrimų ir taip mažiname galimybę apsikeisti nuomonėmis, kaip sekančiai tendencijai, t. y. kaip pagrindui viską supaprastinti. Trečia, bandydami paaiškinti kitų veiksmus negatyviu būdu, judame kraštutinumų link.

Socialinio konstruktyvizmo požiūriu, socialinis darbas yra save reflektuojanti profesija. Motečienė, Naujanienė (2011) remiasi Partono išskirtomis šešiomis pagrindinėmis sritimis, kurios atskleidžia socialinio 
darbo kaip profesijos lauko socialinio konstruktyvizmo paradigmą: 1) svarbu atpažinti terminus, kuriuos vartodami suprantame mus supantị pasauli ir save pačius. Konstruktyvizmas reikalauja ugdyti kritinę pozicija, atsižvelgiant i savo pačiu pasaulio suvokimo interpretacijas; 2) socialinis pasaulis, įtraukiantis mus pačius kaip asmenis, yra socialinių procesų produktas, kuris parodo, kad niekas savaime nèra duotybè ir determinuota pačios gamtos. Nėra jokių esmių daiktų viduje ar žmonėse, kurie būtų paslèpti ir nulemtų, kad žmonès būtų tokie, kokie yra; 3) socialinès kategorijos ir konceptai matomi specifiniuose istoriniuose ir kultūriniuose kontekstuose. Negalime manyti, kad mūsų suvokimas yra neišvengiamai toks pat kaip kitų ir yra arčiau tiesos; 4) žinios apie pasauli yra plečiamos žmonėms kasdieną sąveikaujant ir kalbantis. İvardijami atpažinimo būdai, kurie aprašymus, aiškinimus ir pristatymus kildina iš santykių; 5) kalbos vartojimo praktiką riboja santykiai, kuriuos nulemia ritualai ir tradicijos. Siekiant pokyčiu, reikia konfrontuoti su iššūkiais, kelti idejjas, prasmes, kalba turi evoliucionuoti geraja prasme; 6) refleksyvumo akcentavimas yra socialinio konstruktyvizmo pagrindas, t. y. bandymas kažkieno mintis perfrazuoti ir paversti klausimu stebint, kaip atsiranda alternatyvios temos ir patirties suvokimo konstruktai.

Refleksyvumu grịsta sąveika tarp socialinio darbuotojo, kliento ir konteksto sudaro galimybę keistis visuomenès ir sąmonès struktūroms, kritiškai žvelgiant ị socialinę asmens visuomenėje prigimtį. Kiaunytės, Puidokienès (2011) nuomone, dialogu grịsta laikysena socialinio darbo praktikai teikia galimybę pamatyti reiškinių kitoniškumą, atpažinti skirtybes, priimti tiesos versijas, konstruoti naują žinojimą. Apsikeitimas skirtybėmis autentiškai bendraujant skatina koreguoti save ir savo santyki su kitu bei ieškoti naujų prasmių.

TYRIMO REZULTATAI. Socialinio konstravimo idejja yra ta, kad žmonès subjektyviai, pasak Gergeno (2003), paaiškina ar papasakoja apie save ir pasauli, kuriame jie gyvena. Atliekant ši tyrimą apklausti socialiniai darbuotojai, atskleisdami patirtị, išsakè savo požiūrị i žmogaus su psichine negalia neveiksnumo pripažinimo procesą. Analizuojant gautus tyrimo duomenis, subkategorijos buvo suskirstytos į 9 kategorijas, kurios susistemintos i tris blokus remiantis Samsoniene (2011), jos nuomone, požiūris i neigaliuosius yra paremtas jausmais ir emocijomis, o palaipsniui išsirutulioja požiūrio sudètiniai komponentai: kognityviniai, 
jausminiai ir elgsenos. Van Kesselio, Haano (1993) teigimu, vieningas šių komponentų sąryšis sudaro pagrindą asmens integruotam profesionaliam funkcionavimui, priešingu atveju, kylančios prieštaros tarp asmens mąstymo, veikimo ir jausmų sąlygoja asmenybès vidinius ir išorinius konfliktus, profesines dilemas.

\section{KOGNITYVINIS KOMPONENTAS}

Socialinių darbuotojų mintys apie žmogaus su psichine negalia buvimą visuomenèje. Socialiniai darbuotojai pasakojo, kad jų pirmieji atsiminimai apie žmogu su psichine negalia yra susiję su negatyviais vaizdiniais, su kažko svetimo pajautimu, kad „žmogus yra keistas, kitoks nei kiti“. Informantas prisiminė iš filmų kilusius vaizdinius apie žmogu su psichine negalia. Tai „neatsiejama nuo tramdomujų marškinių, jiems pastoviai varva seilès, vaikšto pasvirusiomis galvomis“. Negatyvūs vaizdiniai suformuoja etiketes, kurios menkina žmogu su psichine negalia. Socialiniai darbuotojai pabrèžè, kad žmonès neigaliuosius vadindavo "psichais", "durniais", „čiudnomis", "kvailelèmis", „mistinèmis būtybèmis", pravardžiuodavo, pavyzdžiui, vadino „šobla jobla“, tai paniekinančiai ir pašaipiai nusako žmogų kaip bedvasę būtybę. Etiketès, performuotos į švelnesnę forma, kaip „durnikè", „durnukas", nepanaikina neigiamų asociacijų apie asmeni su psichine liga, bet aplinkiniams žmonėms atrodo, kad moralinis priekaištas tarsi mažesnis. Tyrime dalyvavę socialiniai darbuotojai nurodè, kad žmogus su psichine negalia dažnai aplinkinius ,"užknisdavo", nes "nusišneka“, ,užknisa su savo poezija“. Socialiniai darbuotojai mano, jog visuomenejje yra mažai institucijų, kurios būtų taip stipriai stigmatizuojamos. Psichiatrijos ligoninè vadinama "durnynu“, „psichuške“. Etiketès priskiriamos ne tik žmogui su psichine negalia, bet ir miestams, gatvėms, kuriose įsikūrusios psichiatrijos ligoninès: ",banguškè", ,liotčikų" mokykla. Skaudvilè ir Švẻkšna tapo psichiatrijos ligoninès sinonimu, o joje buvę žmonès „,̌̌vèkšniniais“", „skaudviliniais“.

Socialinių darbuotojų mintys apie šeimos nuostatas ir emocijas susidūrus su artimo žmogaus psichine negalia. Giddensas (2005) teigia, kad ligos patirtis gali tapti iššūkiu žmogaus savimonès identitetui ir sukelti jo transformacijas, kurios yra veikiamos tiek realių, tiek ir individo i̊sivaizduojamų ar suvokiamų kitų žmonių reakcijų i ligą. Asmuo prisiima 
psichinio ligonio vaidmenį kartu su visais šio vaidmens prietarais, stereotipais ir nuostatomis, prarasdamas savo ankstesnius socialinius vaidmenis. Socialiniai darbuotojai pastebi, kad žmogus su psichine negalia šeimai tampa "našta“, , "praranda šeimoje autoritetą“, yra nuvertinamas. Šeimos nariai yra linkę psichinę ligą tapatinti su neveiksnumu, nes „,ką čia sergančiojo klausi, vis tiek jis sergantis, neturi savo nuomonès". Informantas yra susidūręs su šeimos nuomone, kad „koks čia teisinis neveiksnumas, jeigu jis ir taip neveiksnus“. Informantas pastebi, jog žmogui su psichine negalia priskiriamas "tinginio“ vaidmuo, nes šeimos nariai mano, kad žmonès su psichine negalia „simuliuoja psichinę ligą“. Asmens susirgimas psichine liga, pasak socialinių darbuotojų, šeimos nariams sukelia daug ìvairialypių emocijų: ,gèda prieš visuomenę", ,"kol imanoma, slepia tą liga, o paskui geriausiai pasidaryti neveiksnų, kad niekas nematytų ir kad niekas negirdètų“, "pyktį, kad nesusitvarko“, „pasimetimą". Informantas pastebi, jog šeimoje "santykiai pablogèja, vyksta skyrybos, sveikajam yra labai sunku, nes reikia prižiūrèti ir kartu gyventi“".

Socialinių darbuotojų mintys apie žmogų su psichine negalia kaip klientą. Socialinių darbuotojų nuomone, žmogaus su psichine negalia kalbejjimas yra specifinis, išskiriantis juos iš kitų žmonių, nes "kartais kalba su savimi“" "mąsto, šnekasi patys su savimi“, "žmogus, kuris mato pasauli kitaip“. Socialiniai darbuotojai pastebi, kad žmonės su psichine negalia yra „,kiek apsileidę, apsirengę keistai, neadekvačiai oro sąlygoms“, ,judejjimas kitoks, ir žvilgsnis yra kitoks“. Informantas ìvardija, jog ị žmogų su psichine negalia ,,žiūrime kaip ị vaika, kuriam reikalinga globa".

Socialinių darbuotojų mintys apie žmogaus su psichine negalia neveiksnumą. Neveiksnumas visuomeneje yra suprantamas tik kaip visiškas žmogaus neveiksnumas. Socialiniai darbuotojai susiduria su žmonių, turinčių psichine negalia, nuomone apie neveiksnumą, kurie „sako, kad yra nurašyti“, „mano, kad pažemins, išbrauks iš visuomenès“, mato save kaip „visišką daržovę, kuri nieko nebegali pati pasidaryti, kuri kažkas valgydintų, kažkas nupraustu, kažkas valgyti ruoštų....". Supranta, kad „parašas nebegalios, kad globejjas viską už ji tvarkys“. Informantas pastebi, kad klientas maišo psichinę negalią su neveiksnumu, nes mano, kad „susirgo psichine liga, todèl yra nepakaltinamas ir neveiksnus“. Ši nuomonė parodo sąsają tarp psichinès negalios ir neveiksnumo. Linkas (Germanavičius, 2008) teigia, kad psichikos 
ligonių stigmatizavimas pažeidžia asmens savigarbos ir veiksnumo jausmą bei veikia esmini stigmatizuojamo asmens vertès suvokimą. Su neveiksnumo ir psichinės negalios sutapatinimu susiduriama ir visuomenëje. Informantas teigia, kad visuomenèje yra paplitusi nuomonè „,jei žmogus yra sergantis psichikos liga $\langle\ldots\rangle$, tai ji ir vadina neveiksniu“. Visuomenės požiūriu, psichikos diagnozė prilygsta neveiksnumui. Tyrime dalyvavę socialiniai darbuotojai apie žmogaus su psichine negalia neveiksnumą mano, jog yra ,, apribojimas žmogaus civilinių veiksmų, teisių", ,"apribojimas visiškai žmogaus teisių, išmetimas iš visuomenės <...> visko atėmimas", "tikrai dabar nèra gerai, kai žmogus yra padaromas socialiai mirusiu".

Socialinių darbuotojų mintys apie veiksnius, nulemiančius pripažinimą žmogaus su psichine negalia neveiksniu. Socialiniai darbuotojai mano, kad žmogaus su psichine negalia neveiksnumo pripažinimą lemia jų nebesugebejjimas prižiūrèti savęs, kai „visiškai nesirūpina savo sveikata“, kai "nesusitvarko buities“, kai "praranda socialinius igūdžius“, kai iš viso "negali neprižiūrimas egzistuoti“. Socialiniai darbuotojai pabrèžia finansines problemas, sukeliančias sunkumų tiek neigaliesiems, tiek jų artimiesiems: „bankiniai reikalai“, „pensijų pasièmimai, kreditų pasiėmimai“, "neįvertinus savo galimybių, skolos už komunalinius mokesčius, kitus įsipareigojimus“. Socialiniai darbuotojai įvardija juridines problemas, kai tenka bendrauti su antstoliais, kitais teisésaugos atstovais, kai asmuo su psichine negalia nebegali pasikeisti asmens dokumentǔ, priimti palikimo, net „negali pasirašyti už buto renovaciją“, praktiškai visų civilinių, juridinių santykių atvejais, „,kur reikalingi tèvų parašai, ir tėvai nebepasirašo ar nebesutinka pasirašyti“. Taip pat socialiniai darbuotojai išskiria žmogaus su psichine negalia pritapimo visuomenèje problemą. Jie teigia, jog žmogui su psichine negalia ,svarbu žinoti, kad visuomenëje yra privalomos taisyklès ir visi jų turime laikytis“, bet, anot socialinio darbuotojo, jie „mąsto kitaip, daro visiškai kitaip - mūsų visuomenei nesuprantamus dalykus <...> Nesupranta, ką jis daro kitaip, nes visuomenę i̇sivaizduoja pagal save“. Informantas mano, kad žmogaus su psichine negalia nesilaikymas visuomenės normų ji supriešina su pačia visuomene: „Tokios yra visuomenès normos, kad jis gyvena daugiabutyje, jis negali gyventi ten su tarakonais ir visokiais ten kitais gyviais. Ne mes, o visuomene jau būna ji išmetusi...>". Socialinis darbuotojas pastebi, jog žmogus su psichine negalia tampa savotišku kliuviniu visuomenei, kai "trukdo institucijoms, vaikšto ir rašo skundus visokiausius". 


\section{JAUSMINIS KOMPONENTAS}

Socialinių darbuotojų patiriami jausmai dalyvaujant žmogaus su psichine negalia neveiksnumo nustatymo procese. „Kai ateina giminès, tai mes labai dažnai konsultuojam apie neveiksnumo procesą“, teigia socialinis darbuotojas. Kitas informantas kalba, jog padeda „surinkti dokumentus dèl neveiksnumo, atskirais atvejais parašyti pareiškimą i teismą dèl neveiksnumo" pripažinimo. Tai atvejai, kai socialiniam darbuotojui nekyla dvejonių, vidinių prieštaravimų. Socialinis darbuotojas susiduria su sudètingomis situacijomis, ị kurias patenka asmenys, patyrę insulta, kitas traumas, sergantys senatvinėmis demencijomis, kitomis ligomis, kurios turi ryškiai išreikštą intelekto deficita, arba komoje esantys asmenys, o jų šeimos nariams tenka spręsti neatideliotinus klausimus. Tokiais atvejais yra būtinas poreikis pripažinti asmenį neveiksniu ir ji globoti.

Tačiau tyrime dalyvavę socialiniai darbuotojai susiduria ir su tokiais atvejais, kai patiria vidinius konfliktus, kai jiems iškyla dilema. Kaip suteikti žmogui su psichine negalia visapusišką pagalba, kai žmogus serga šizofrenija, bipoliniu sutrikimu, manijomis, psichoziniais sutrikimais ir kitomis ligomis. Socialinis darbuotojas sako, jog stengdamasis padèti išsaugoti žmogaus teises, prisiima gynëjo vaidmenį, „vis tiek turi pasakyti taip, kad apgintum to žmogaus interesus", bandydamas išsaugoti žmogaus su psichine negalia veiksnumą. Socialinis darbuotojas prisimena, kad „buvo nuspręsta ją pripažinti neveiksnia, tada pasipriešinome ir iki šiol ji savarankiškai gyvena...". Kita socialinė darbuotoja teigia, kad yra „.... iškovojusi asmeniškai tris ar keturis, kurie buvo paduoti i teismą ir nepripažinti neveiksniais".

Apklausti socialiniai darbuotojai pabrèžè, jog dalyvaudami žmogaus su psichine negalia neveiksnumo pripažinimo procese jaučiasi nereikšmingi, atliekantys statisto vaidmeni. Socialiniai darbuotojai sako: „Supranti, socialiniam darbuotojui mažai galių, mažai jo kompetencijai pasireikšti galimybių“, , "dažniausiai jaučiuosi dèl statistikos, dèl popieriaus, buvimas dèl buvimo, nes priklauso tau būti, tu privalai ateiti“, „būna taip, kad jeigu jisai nėra mūsų ịskaitoje, bet aš turiu eiti ị teismă, nes negaliu šaukimo ignoruoti, bet teisme sakau, kad nieko apie ji nežinau ir siūlau teismui vadovautis teismo psichiatro išvada". Socialinis darbuotojas prisimena atvejus, kai „du kartus prieštaravo globejų skyrimui, bet i tai nebuvo atsižvelgta". Socialinis darbuotojas atsiduria vidines ittampas keliančioje profesineje situacijoje, kai, viena vertus, kaip socialiniam 
darbuotojui, besilaikančiam etikos kodekso, svarbu ginti kliento teises ir interesus, o kita vertus, - stinga instituciškai reglamentuotos galios atstovauti žmogui su psichine negalia.

Socialinių darbuotojų patiriami jausmai kitų sričių specialistų atžvilgiu. Socialiniai darbuotojai, dalyvaudami žmogaus su psichine negalia neveiksnumo pripažinimo procese, gydytojų atžvilgiu patiria prieštaringus jausmus: „...Jeigu matai, kad gydytojas yra neteisus, tai dažniausiai prieštarauji <...>. Klausytis ne visada klausosi, nes gydytojai nori spręsti patys...", ,....neretai tenka paklusti psichiatro diktatui, nors kartais mokame įrodyti, kad ir mūsų tiesa". Socialinis darbuotojas mano, jog „ekspertai „yra aukštumoje“, tačiau jam kelia abejonę, „ką galima spręsti apie žmogu, pabendravus su juo apie valandą $\langle\ldots$,$\rangle , bet gydy-$ tojas viską žino, ekspertas viską žino...". Eksperto išvada nulemia visą žmogaus su psichine negalia gyvenimą. Informantas pastebi tendencija, kad ekspertai savo išvadose vis „dažniau rašo, kad žmogus dalyvautu teismo posèdyje", tai rodo neveiksnumo pripažinimo proceso pokyčius.

Socialiniai darbuotojai pastebi teisëju pasitikejjimą ekspertu kaip medicinos institucijos atstovu, „vadovaujasi medžiaga, kuri yra surinkta“, tačiau "labai formaliai vertina socialinių darbuotoju pasisakymus". Pasak socialinio darbuotojo, asmens neveiksnumo pripažinimo procesas vyksta formaliai: „....pavyzdžiui, Klaipėdos teisme, kai yra vienas popierius, yra antras popierius, yra trečias popierius, visi sako, kad tinka - viskas, dedam štampa, jis jau neveiksnus“.

Socialiniai darbuotojai įvardija ir tam tikrus pozityvius asmens su psichine negalia neveiksnumo pripažinimo proceso poslinkius, kai „...dažniau kviečiasi tuos žmones ị teismą“, kai teisẻjai teiraujasi socialinio darbuotojo „,...po neveiksnumo posėdžio $<\ldots .>$, ką reikètų paskirti globejju iš tų dviejų kandidatų", tačiau šiuo metu socialiniams darbuotojams diskusinius klausimus kelia atnaujintas LR Civilinio proceso kodekso 56 straipsnis, pagal kurị institucijų atstovais civilinėse bylose gali būti tik aukštaji teisinị išsilavinimą turintys asmenys. Šis teisinis reikalavimas apriboja socialinių darbuotojų galimybes dalyvauti neveiksnumo pripažinimo procese bei atstovauti kliento interesams. 


\section{ELGSENOS KOMPONENTAS}

Socialinių darbuotojų habitualizuotų veiksmų ir galimų žmogaus teisių pažeidimų institucionalizuotoje neveiksnumo nustatymo praktikoje patirtis. Socialiniai darbuotojai pastebi, jog žmogus su psichine negalia yra nesupažindinamas su neveiksnumo byla. Asmuo nežino, kad jam pradèta procedūra dẻl veiksnumo atėmimo: "Stengiamasi nesakyti, nors gal reikètų pasakyti tam žmogui <...> Realiai žmogui dažniausiai nepranešama“, „,...ne visada mes tą sakome, nes šiaip žmonès kviečiami i teismą ne visada vienodai priima, kartais būna, kad iki galo žmogui neišaiškinama". Nesupažindinant asmens su byla yra pažeidžiami LR Neigaliụjų socialinès integracijos i̇statymo 3 straipsnyje nurodomi principai dèl lygių teisių, lygių galimybių, diskriminavimo prevencijos, visapusiško dalyvavimo.

Žmogus su psichine negalia turi teisę pasirinkti sau priimtiną globėją. Tai reglamentuoja LR Civilinio proceso kodekso 491 ir 507 straipsniai, tačiau socialiniai darbuotojai teigia, kad „...labai retai būna atvejų, kai neveiksnus asmuo išreiškia, ką nori matyti savo globeju“ , , paprastai ju niekas ir neklausia, daugiau kreipiama dèmesio, kas gali būti globejjais $<$...> Oficialiai niekas jų neklausia apie globejo pasirinkimą“, o ", dèl globejju apsitariama pačioje šeimoje".

Socialiniai darbuotojai susiduria su globejų motyvacijos problema. Socialinis darbuotojas mano, jog kai kuriais atvejais būsimi globejjai turi asmeninių tikslų: „,...globejjas niekur nedirba ir gyvena iš neveiksnaus asmens lèšu, pensijos, slaugos pinigų. Matau, bet ką aš galiu padaryti.“. Kitas atvejis: „,...iš šalies puikiai matèsi, kad tai yra turto klausimai, nes žmogus turëjo du butus skirtinguose miestuose bei gana padorią sąskaitą banke. Vieni artimieji net buvo kitos šalies piliečiai, bet vis tiek veržėsi būti globejjais“. Tokie atvejai socialiniams darbuotojams kelia daugiausia klausimų: kaip užtikrinti globą ir priežiūrą, pripažinus asmeni su psichine negalia neveiksniu.

Tyrime dalyvavę socialiniai darbuotojai ịvardijo globejų kontrolès problemą. Socialiniai darbuotojai teigè, jog „metodikos nèra. Nemanau, kad yra tinkama kontrolè, nes, kaip sakiau, nèra aiškaus apibrèžimo ir globèjų kontrolès mechanizmo..." , ,"nežinau, ịstatymo tokio grynai tiesioginio nèra, bet prižiūrime, o kas lieka...". LR Civilinio kodekso 3.278 straipsnis reglamentuoja, kad globos ir rūpybos institucijos privalo kontroliuoti, ar globejjas tinkamai atlieka savo pareigas, tačiau socialiniam darbuotojui kyla abejonè dèl globėjų kontrolès: „Ar kas nors kontroliuoja, kaip jie 
tą atlieka? Mano nuomone, - nekontroliuoja“. Socialinis darbuotojas, noredamas atstovauti žmogaus su psichine negalia interesams, susiduria su ribotomis galimybèmis, nes neturi teisinio pagrindo reikalauti iš globejjo atskaitomybès: „, Esam porą kartų taip nusvilę, kad bandème tikrinti, bet žmonès apskundè, kokiu pagrindu mes tikriname, nes nėra tokio įstatymo, pagal kurį mes turime teisę tikrinti“.

Kita socialinių darbuotojų išsakyta aktuali problema: „Kai niekas nenori būti globëju, institucijos taipogi atsisako globos", o globa žmogui su psichine negalia, anot socialinių darbuotoju, yra būtina. Gydymo įstaigos nenori prisiimti globejo statuso, nes teikia gydymo paslaugas, o globa yra socialinė problema. Nors LR Civilinio kodekso 3.240 straipsnis reglamentuoja, kad laikinai, kol nèra pastovių globejuu, globos ir rūpybos funkcijas gali atlikti ta įstaiga, kurioje neveiksnus žmogus yra, tarp jų ir gydymo isstaigos.

Socialiniai darbuotojai teigia, kad, dalyvaudami bylose dèl asmens su psichikos negalia neveiksnumo pripažinimo, kartais būna jų nematę, „....nes kai kurie artimieji eilę metų važinejja i polikliniką išsirašinèti vaistus", "tada skambini ir klausi, apie juos, artimuosius". Toks darbo trūkumas palieka galimybes šeimos nariams kryptingai teikti informaciją apie žmogų su psichine negalia. Tai prieštarauja JT Neigaliųjų teisių konvencijos 12 straipsnio 4 dalyje nurodomoms garantijoms, kurios turi užtikrinti priemones, susijusias su teisinio veiksnumo igyvendinimu, kad būtų paisoma asmens teisių, valios ir pageidavimų, dèl jų neatsirastų interesų konflikto ir nebūtų piktnaudžiaujama įtaka, kad jos būtų proporcingos ir pritaikytos su asmeniu susijusioms aplinkybėms.

JT Neigaliųu teisių konvencijos 12 straipsnio 2 dalyje nurodoma, kad neigalieji, kaip ir visi kiti asmenys, turi teisini veiksnumą visose gyvenimo srityse. $\mathrm{O}$ žmogaus su psichine negalia neveiksnumo pripažinimu visiškai apribojamos jo teisès. Pasak socialinių darbuotojų, ,jie nebegali rinktis nei gydytojo, negali balsuoti, $<\ldots>$ bet jie daug ko iš tikrųjų negali daryti“, ,"negali išreikšti savo nuomonès, savo pozicijos" ${ }^{\prime}$, ,...jie sužino, <...> kad jų niekas nebeklaus". Neveiksnus žmogus tampa priklausomas nuo globejo malonės, sprendimus priiminėja kiti.

Socialinis darbuotojas pastebi, kad asmens neveiksnumo pripažinimas yra „...lengviausias variantas patalpinti i globos namus“, lengviausias problemos sprendimo būdas. Neveiksnumo pripažinimas tampa, anot 
kito socialinio darbuotojo, tarytum legalia prievartos forma, kai žmogui su psichine negalia atimama pasirinkimo teisè: „,...pripažino neveiksniu, kad galètų išvežti i pensionata, nes jis pats nebūtų sutikęs važiuoti“.

Socialiniai darbuotojai išsakè, jog „....būtų buvę galima pripažinti ne visiškai neveiksniais, o ribotai neveiksniais“, , „...praktiškai iš ligoninès kiek esame vežę neveiksnių žmonių, tai kokiems 80 procentų galèjo būti pritaikomas ribotas veiksnumas“" ",tas asmuo, mano nuomone, su tam tikra priežiūra galèjo gyventi vienas“, ,"neveiksnumas yra per daug skaudus tam žmogui, bet ribotas veiksnumas yra pats tas“. Žmogaus su psichine negalia visiško neveiksnumo pripažinimas visam gyvenimui prieštarauja JT Neigaliụjų teisių konvencijos 12 straipsnio 4 dalyje nurodomoms garantijoms, kuriomis užtikrinama, kad priemonès, susijusios su teisinio veiksnumo igyvendinimu, būtų taikomos kuo trumpesni laiką ir kad jas reguliariai peržiūrètų kompetentinga, nepriklausoma ir nešališka institucija ar teismas.

Socialinių darbuotojų nuomonè apie veiksmus, koreguojančius neveiksnumo nustatymo procesą. Socialiniai darbuotojai pabrèžia teoriniu žinių apie psichiatriją gilinimą: ,,...net negalvojau, kad tiek daug yra psichinių ligų“, , „...apie jų elgesi norejosi daugiau sužinoti“. Teorinių žinių apie psichiatriją gilinimas padètų socialiniams darbuotojams, taip pat ir kitiems specialistams, dalyvaujantiems teismo procese, kai siekiama nustatyti žmogaus su psichine negalia neveiksnuma, argumentuotai prieštarauti užginčijant eksperto išvadą.

Tyrime dalyvavę socialiniai darbuotojai pasigenda socialinių paslaugų tinklo išvystymo: „paslaugu i i namus trūksta, bet situacija pagerejjusi, yra „lakštutès", ,manau, kad neveiksnumas būtų mažiau taikomas <...>, jei būtų savarankiško gyvenimo namai, išplètoti dienos centrai $<\ldots>$, geresnès kokybės ir nereikètų mokèti, būtų išvystytos socialinès paslaugos namuose“. Kaip vieną iš būdų plèsti socialines paslaugas, socialiniai darbuotojai siūlo atvejo vadyba, nors patys abejoja, ar finansiškai visuomenė pajėgi dirbti tokiais principais: „Visų pirma mūsų visuomenẻje Lietuvoje nèra tiek socialinių darbuotojų, kurie galètų su žmogumi dirbti. Jei būtų atvejo vadyba ir jis turètų penkis žmones, tai taip, šitokiu atveju galètų žaisti“".

Socialiniai darbuotojai mano, kad problemą galima būtų spręsti taip: „....būtų labai tikslinga pripažinti ribotai veiksniais“. Riboto veiksnumo nustatymas mažintų ir paties asmens baimę būti psichiškai neigaliu, nes tai, jo požiūriu, prilygsta visiškam neveiksnumui. Socialiniai darbuotojai 
sutinka, kad žmogui su psichine negalia turètų būti paliktos kai kurios „..teisès, kad jie galètų gerai jaustis visuomenèje“.

Kaip alternatyvą ribotam veiksnumui socialiniai darbuotojai siūlo asmens su psichine negalia konkrečių veikų apribojimą: „„<..> ar teismo sprendimas pensiją pasiimti, prižiūrint ten kažkokiam žmogui, ar inicijuoti tos pensijos išleidimo priežiūrą", „manau, turètų būti galima apriboti kai kurias žmogaus funkcijas ir veiklas arba kai kurias gyvenimo sritis, o ne apriboti jo veiksnumą“. Tai skatintų žmogų su psichine negalia dalyvauti visuomenès veikloje, mažiau traumuotų nei visiško neveiksnumo statuso pripažinimas.

Nors LR Civilinio proceso kodekso 469 straipsnyje nurodoma, kad, jeigu neveiksniu pripažintas asmuo pasveiksta ar labai pagerejja sveikatos būklè, jis gali būti pripažintas veiksniu, arba iš visiškai neveiksnaus ribotai veiksniu, tačiau realybeje labai retais atvejais neveiksnūs žmonės atgauna savo veiksnumą. Iš esmės neveiksnus žmogus su psichine negalia negali tapti ribotai veiksniu, nes tai prieštarautų LR Civilinio kodekso 2.11 straipsniui, kuris reglamentuoja, kas gali būti pripažinti ribotai veiksniais. Šie paminèti straipsniai konfrontuoja tarpusavyje. Socialinis darbuotojas siūlo įvesti „....terminą iki tol, kol pagerės būklè <...>. Buvo žadama, kad kas dvejus ar kas trejus, ar penkerius metus bus peržiūrimas neveiksnumas". Kritiškai mąstydami, socialiniai darbuotojai supranta, kad kiekvieno neveiksnaus žmogaus su psichine negalia neveiksnumo statuso peržiūrèjimas atimtų teismams ir kitoms institucijoms daug laiko ir lěšų, tačiau siūlo, kad ,...būtų paprasčiau, susirenka komisija, kuri nusprendžia, kam reikia pradèti veiksnumo grąžinimo procesą. Jei mato, kad situacija nepasikeičia, tai palieka toliau neveiksnumą bet jei mato, kad pagerejo, tada pradeda emancipavimo procedūrą teisminiu keliu“.

Socialinis darbuotojas mano, jog galètų būti tarsi „....koks žmogaus su psichine negalia oficialus patarejjas...". Socialiniai darbuotojai pasigenda teisinio pagrindo, kuris padètu atstovauti žmogui su psichine negalia kasdienejje veikloje: „,...istaigose dažnai klausia, ar turi jo igaliojimą kaip tu jam atstovauji?“. Pavyzdys - prieš keletą metų galiojusi tvarka, kai igaliojimą galejo patvirtinti gydymo i̇staigų vadovai. Socialiniam darbuotojui tikrai būtų lengviau, turint žmogaus su psichine negalia igaliojima, atstovauti jo interesams. 


\section{IŠVADOS}

Žmogaus kalboje simboliais užkoduotas jo paties santykis su tikrove. Tyrimas rodo, jog visuomenejje neretai žmogaus psichinè negalia tapatinama su jo neveiksnumu. Simultaniškas psichinès negalios ir neveiksnumo terminų vartojimas atskleidžia vienpusi, stigmatizuojanti reiškinio matyma, kai pats žmogus su psichine negalia supranta savo bejègiškumą kurị patvirtina ir jo artimoji aplinka bei pripažista / itteisina institucijos. Kaip atsitinka, kad skirtingų terminų ribos ir jų prasmės taip suartejja? Istoriškai ir kultūriškai nulemti socialiniai visuomenės procesai formuoja sampratas, kuriomis pasidalijama ir kurios, būdamos priimtos, virsta habitualizuotais veiksmais. Socialinio konstruktyvizmo požiūriu, svarbu ugdyti kritini mąstyma, kritiškai suvokti tikrovę ir ieškoti alternatyvių prasmių plètojant dialogą su savimi ir kitu.

Žmogaus su psichine negalia padètis visuomenėje yra tos pačios visuomenės moralumo, sąžiningumo, tolerancijos atspindys. Priklausomai nuo to, kaip visuomenẻ konstruoja juridinį, medicininį, socialinį žmonių tarpusavio santykių susidūrus su asmens psichine negalia procesa, galima atpažinti, $i$ ką šis procesas yra orientuotas, ar i rūpestị ir globą atstovaujant žmogui ir ginant jo teises, ar i galios ir kontrolès išraiška, grindžiamą nekintančiu „žinojimu“. Socialinis darbuotojas, suvokdamas institucionalizacijos procesus, kurie lemia žmogaus su psichine negalia socialinę atskirti, stigma, ir juos reflektuodamas galètų siekti nusistovejjusių, rutiniškų veiksmų pokyčių, tačiau šiandien socialinis darbas visuomenejje vis dar sunkiai matomas ir nepakankamai vertinamas. Tyrimo duomenų analizè rodo, kad socialinio darbuotojo vaidmuo nèra aiškiai apibrėžtas. Medicinos institucijoje pripažistamas gydytojų autoritetas, socialiniai darbuotojai dažnai net socialiniais klausimais neturi sprendžiamojo balso. Santykių su kolegomis atžvilgiu socialiniai darbuotojai jaučiasi nelygiaverčiai. Žmogaus su psichine negalia neveiksnumo nustatymo procese socialiniai darbuotojai susiduria su profesinio vaidmens prieštaromis, kai, viena vertus, - svarbu ginti kliento teises ir interesus, o kita vertus, - stinga instituciškai reglamentuotos galios atstovauti žmogui su psichine negalia.

JT ekspertu pranešime Disability No Justification for Denying People's Right to Make Their Own Decisions - UN Experts (2014) Žmonių su negalia teisių komiteto narè T. Degener nurodo, jog žmonès su negalia turi būti 
palaikomi jiems priimant sprendimus, tačiau nereikia priimti sprendimų už juos. O Lietuvoje, kaip rodo tyrimo duomenys, i̇ žmonių su psichine negalia nuomonę neveiksnumo statuso pripažinimo klausimais mažai arba visai neatsižvelgiama. Nors nuo 2010 m. JT Neigaliụjų teisių konvencijos reikalavimai įsigaliojo Lietuvoje, tačiau permainos suteikiant neveiksnumo statusą neskuba. Tik 2014 m. balandžio 2 d. LR Vyriausybei pateiktas Civilinio kodekso pakeitimo įstatymo projektas, kuriuo numatomas 2.10 straipsnio pakeitimas dèl asmens pripažinimo neveiksniu tam tikroje srityje, 2.10 straipsnio papildymas dèl neveiksnaus asmens būklès peržiūrèjimo bei 2.11 straipsnio pakeitimas, kuriame nurodoma, jog asmuo dèl psichikos sutrikimo gali būti pripažintas ribotai veiksniu. Tikètina, kad aptariant neveiksnumo instituto probleminius klausimus ir reformuojant šio proceso procedūras atsiras platesnè erdvė ir socialiniam darbui kaip pagalbos žmogui profesijai.

\section{REKOMENDACIJOS}

Socialinio darbuotojo veiklos, siekiant sumažinti žmogaus su psichine negalia pažeidžiamuma, reformavus su neveiksnumo statusu susijusias procedūras, perspektyvos:

Socialinio darbuotojo pagalba žmogui su psichine negalia priimant sprendimus, jei, asmeniui prašant ir teismui nusprendus, būtų nustatyta, jog žmogaus su psichine negalia pagalbos konkrečiose gyvenimo sferose poreikis yra tikslingas.

Socialinio darbuotojo pagalba îtvirtinus riboto veiksnumo kategorija psichikos negalia turinčiu asmenu atžvilgiu: padèti klientui kreiptis i teismą dèl riboto veiksnumo peržiūrèjimo, rūpintojo nušalinimo arba pakeitimo kitu bei teikti pagalbą kitais rūpimais klausimais.

Socialinio darbuotojo pagalba neveiksniam asmeniui kreipiantis i teisma dèl jo neveiksnumo statuso peržiūrèjimo arba apimties pakeitimo: Valstybinèje teismo psichiatrineje tarnyboje dirbantis socialinis darbuotojas, kuris bendradarbiautų su visomis suinteresuotomis grupèmis, galètų teikti informaciją apie žmogaus su psichine negalia socialinę situaciją teismui. 


\section{LITERATŪRA}

1. Andrikienè-Pūraitè, D. (2012) Kai kurie Lietuvoje teisės aktuose ịtvirtinto neveiksnumo instituto probleminiai aspektai. Teisés problemos. Lietuvos teisės institutas, 3 (77): 72-102.

2. Berger, P. L., Luckmann, T. (1999) Socialinis tikrovés konstravimas. Vilnius: Pradai.

3. Disability No Justification for Denying People's Right to Make Their Own Decisions - UN Experts. Internetinè prieiga: http://www.ohchr.org/EN/ HRBodies/CRPD/Pages/GC.aspx [Žiūrèta: 2014-05-16].

4. Europos žmogaus teisių ir pagrindinių laisvių apsaugos konvencija. Valstybés žinios, 1995-05-16: 40-987.

5. Finlay, L. (2012) Debating Phenomenological Research Methods. Hermeneutic Phenomenology in Education. Friesen, N. at al. (eds.). Published by: Sense Publishers: 17-37.

6. Gergen, K. J. (2003) Knowledge as Socially Constructed. Gergen, M., Gergen, K. J. (eds.) Social Construction a Reader. London: Sage Publications: 15-17.

7. Gergen, K. J., McNamee, Sh., Barrett, F. J. (2001) Toward Transformative Dialogue. International Journal of Public Administration. Publisher: Taylor \& Francis Ltd, 24 (7\&8): 679-707.

8. Germanavičius, A. (2008) Bendruomenès (socialinès) psichiatrijos pagrindai. Psichikos ligoniu reabilitacija ligoninèje. Vilnius: BMK.

9. Germanavičius, A., Povilaitienė, I. (2010) Pirmasis psichozés epizodas: biopsichosocialinis modelis. Vilnius: Vilniaus psichosocialinès reabilitacijos centras.

10. Giddens, A. (2005) Sociologija. Kaunas: Poligrafija ir informatika.

11. Jungtinių Tautų Neigaliujų teisių konvencija ir jos fakultatyvus protokolas. Valstybès žinios, 2010-06-19: 71-3561.

12. Jungtinių Tautų Visuotinė žmogaus teisių deklaracija. Valstybés žinios, 2006-06-17: 68-2497.

13. Kiaunyte, A., Puidokienė, D. (2011) Dialogas kaip ugdomasis susitikimas socialinio darbo kontekste. Acta Paedagogica Vilnensia, Vilniaus universiteto leidykla, 27: 124-138.

14. Kriščiūnas, A. (2002) Psichikos ligos ir mes. Vilnius: Ciklonas.

15. Lietuvos Respublikos Civilinio kodekso pakeitimo istatymo projektas (2014-04-02). Nr. XIIP-1656. Internetinė prieiga: http://www3.lrs.lt/pls/inter3/ dokpaieska.showdoc_l?p_id=468350\&p_tr2=2 [Žiūrèta: 2014-05-18].

16. Lietuvos Respublikos Civilinio proceso kodeksas (2002). Vilnius: Mūsų saulužè.

17. Lietuvos Respublikos Civilinis kodeksas (2004). Vilnius: Mūsų saulužè.

18. Lietuvos Respublikos Konstitucija. Valstybés žinios, 1992, 33-1014 (1992-11-30).

19. Lietuvos Respublikos neigaliųu socialinès integracijos įstatymas, $2004 \mathrm{~m}$. gegužès $11 \mathrm{~d}$. Nr. IX-2228. 
20. Lietuvos Respublikos Vyriausybès Psichikos sveikatos strategijos igyvendinimo 2011-2013 metų tarpinstitucinis veiklos planas, $2011 \mathrm{~m}$. liepos 13 d., nr. 888 .

21. Lietuvos socialiniu darbuotoju etikos kodeksas (1998). Vilnius: Lietuvos socialinių darbuotojų asociacija.

22. Motečienė, R., Naujanienė, R. (2011) Socialinių paslaugų sistemos dalyvių, socialinių darbuotojų ir klientų patirties kritinè refleksija. Socialinis darbas. Patirtis ir metodai. VDU leidykla, 7 (1): 9-30.

23. Nemanytė, M. (2012) Teisinis veiksnumas Lietuvoje. Klubo „13 ir KO“ žinios, 4 (58): 5-7.

24. Payne, M. (2005) Modern Social Work Theory. Publiched by: Palgrave Macmillan.

25. Perminas, A., Goštautas, A., Endriulaitienè, A. (2004) Asmenybè ir sveikata: teoriju squadas. Kaunas: VDU leidykla.

26. Pivorienè, J. (2003) Socialiniai neigalumo aspektai: žmogui reikia žmogaus. Kaunas: VDU leidykla.

27. Radavičius, L. E. (2004) Teisés psichiatrija: istorija ir dabartis. Vilnius: MRU.

28. Samsonienè, L. (2011) Negalios fenomenas integraliame ugdymo ir sporto procese. Vilnius: Vilniaus universitetas.

29. UN Convention on the Rights of Persons with Disabilities. Committee on the Rights of Persons with Disabilities, Eleventh session, 31 March-11 April 2014. General comment No 1.

30. Van Kessel, L., Haan, D. (1993) The Dutch Concept of Supervision: Its Essential Characteristics as a Conceptual Framework. The Clinical Supervisor, 11 (1): 5-25.

31. Ward, A. D. (1999) Naujas požiūris: Sutrikusio intelekto asmenys: teisinis reguliavimas Rytų Europos šalims. Šiauliai: Saulès delta.

\section{SUMMARY}

CONSTRUCTION OF INCAPACITY OF HUMAN WITH MENTAL DISABILITIES: DILEMMAS OF A SOCIAL WORKER

In the article, construction of incapacity of a human with mental disabilities is being analyzed on the basis of the experience of social workers. A critical viewpoint towards institutionalized social reality of incapacity construction based on the knowledge practices is being presented; reflexive nature of social work and dialogic relationship are being actualized. 
The research was conducted in 2013, by questioning six social workers from Klaipeda. For the research target, criterion-selection as well as social workers working with people with mental disability and involved in the incapacity recognition process were chosen. Qualitative research recognition object is based on the phenomenological strategy when other people's experience is borrowed to reveal the phenomenon under investigation. For the data collection an interview method was chosen. The results of the research were presented by carrying out qualitative content analysis. The results show that the social workers are faced with professional dilemmas when confrontations between their thought, feelings and behavior appear. In the cognitive level, the social workers encounter with labeling and stigmatization of a human with mental disabilities in society, their devaluation in the near environment, mental disability identification with incapacity. In sensual level, social workers in relation to the client are confronted with professional role discrepancies, when on the one hand it is important to protect the client's rights and interests, and on the other hand, there is the lack of institutionally regulated power to represent a human with mental disabilities. In collegial relationships with experts social workers feel themselves unequal, in a supernumerary role. In behavioral level, social workers confront with possible violations of human rights when a human with mental disabilities is not familiarized with their case, does not participate in the selection of a patron, involuntarily is placed in a foster home or the institution does not assume patronage. In the article the author presents recommendations in which perspectives of a social worker to reduce vulnerability of a human with mental disabilities are foreseen. 